\title{
Development of a New Titanium Powder Sintering Process with Deoxidation Reaction Using Yttrium Metal
}

\author{
Akihiro Iizuka ${ }^{1,2, * 1}$, Takanari Ouchi ${ }^{1, * 2}$ and Toru H. Okabe ${ }^{1}$ \\ ${ }^{1}$ Institute of Industrial Science, The University of Tokyo, Tokyo 153-8505, Japan \\ ${ }^{2}$ Department of Materials Engineering Graduate School of Engineering, The University of Tokyo, Tokyo 113-8656, Japan
}

Oxygen (O) contamination in titanium (Ti) is difficult to control using conventional Ti powder-metallurgy technologies, owing to the strong affinity between $\mathrm{Ti}$ and $\mathrm{O}$. In this study, we developed a new sintering process that can remove $\mathrm{O}$ from Ti by placing Ti green and yttrium (Y) in molten salt. This study demonstrates that the $\mathrm{O}$ concentration in Ti can be reliably controlled in the range of $200-2000$ ppm $\mathrm{O}$ by varying $a_{\mathrm{Y}}$ in the $\mathrm{Y} / \mathrm{Y}_{2} \mathrm{O}_{3}$ equilibrium at $1300 \mathrm{~K}$ in $\mathrm{NaCl}-\mathrm{KCl}(l)$, such that the sintering reaction of Ti powder simultaneously proceeds. Furthermore, it is also shown that the $\mathrm{O}$ concentration in $\mathrm{Ti}$ can be reduced to $30-60 \mathrm{ppm} \mathrm{O}$ in $\mathrm{YCl}_{3}(l)$ in the sintering process, when the $\mathrm{Y} / \mathrm{YOCl} / \mathrm{YCl} l_{3}$ equilibrium is employed. This study demonstrates the feasibility of a new sintering process that can control the $\mathrm{O}$ concentration in Ti to approximately 30-2000 ppm O. The process ensures economical rationality because the cost of Y metal is negligibly small in recent years. By developing this process, inexpensive high-O-concentration Ti powder can be applied for fabricating the desired low-O-concentration Ti products. [doi:10.2320/matertrans.MT-M2019340]

(Received November 19, 2019; Accepted January 28, 2020; Published March 25, 2020)

Keywords: low-oxygen titanium, rare earth metals, sintering, molten salt

\section{Introduction}

Titanium (Ti) and Ti-alloy (Ti-6 mass\% Al-4 mass\% V, etc.) have desirable properties such as low weight, high strength, corrosion resistance, and biocompatibility. ${ }^{1-4)}$ Additionally, Ti has an abundant natural resource, and Ti material is expected to become a major industrial metal such as steel and aluminum. ${ }^{5,6)}$ However, the current production costs of Ti products are much higher than those made from common metals so that the use of $\mathrm{Ti}$ is limited to high-value-added products for specific applications, such as aircraft parts. ${ }^{7)}$ The high production cost of Ti products is caused by inefficient, specialized, and high-cost techniques to control the purity of $\mathrm{Ti}$ in smelting and machining processes. This is mainly because Ti has an extremely strong affinity for oxygen $(\mathrm{O})$ at high temperatures. ${ }^{7}$

Powder metallurgy of Ti (PM-Ti) is suitable for producing Ti products, because it can decrease the number of hightemperature processes in machining (a near-net-shaped process). In recent years, PM-Ti technologies (e.g., 3Dprinting) fields have advanced rapidly worldwide. Moreover, many new smelting methods for Ti were developed to reduce smelting costs and designed to produce Ti powder. ${ }^{8-11)} \mathrm{PM}-\mathrm{Ti}$ has attracted much attention as a critical technology to enable the widespread use of $\mathrm{Ti}$ in our society.

With conventional PM-Ti technologies, the increase of the $\mathrm{O}$ concentration in $\mathrm{Ti}$ during the sintering process is unavoidable owing to the strong affinity between $\mathrm{Ti}$ and $\mathrm{O} .{ }^{12)}$ As the $\mathrm{O}$ concentration in $\mathrm{Ti}$ increases, the tensile strength also increases because of the solid solution strengthening effect, but the ductility of $\mathrm{Ti}$ deteriorates significantly. ${ }^{13-17)}$ During the manufacture of low-O-concentration Ti products, expensive pure Ti powder with low-Oconcentrations (e.g., 200-400 USD $\left.\mathrm{kg}^{-1}\right)^{18,19)}$ is required as starting material, resulting in high production costs.

\footnotetext{
${ }^{* 1}$ Graduate Student, The University of Tokyo

${ }^{* 2}$ Corresponding author, E-mail: t-ouchi@iis.u-tokyo.ac.jp
}

Considering the current trade-offs between strength and ductility, it would certainly be beneficial to develop a new deoxidation technology to control the $\mathrm{O}$ concentration in $\mathrm{Ti}$ to 100-2000 mass ppm O. The deoxidation technology will establish a novel sintering process that can produce $\mathrm{Ti}$ products with the desired $\mathrm{O}$ concentration starting from an inexpensive high-O-concentration Ti powder.

Until recently, a variety of methods that can produce sintered $\mathrm{Ti}$ with low-O-concentrations have been proposed and developed (Table 1). ${ }^{20-34)}$ Generally, the sintering process of $\mathrm{Ti}$ is conducted in an inert-gas atmosphere or a vacuum. However, as shown in Table 1 , the $\mathrm{O}$ concentration in $\mathrm{Ti}$ is inevitably increased in inert-gas and vacuum states during the sintering process. This occurs, because the partial pressure of $\mathrm{O}_{2}$ (i.e., $\mathrm{O}_{2}$ potential), $p_{\mathrm{O}_{2}}$, must be extremely low to directly remove $\mathrm{O}$ from $\mathrm{Ti}$, owing to the strong affinity between $\mathrm{Ti}$ and $\mathrm{O}$. Based on equilibrium theory, the relationship between the $\mathrm{O}$ concentration in $\beta$-Ti $\left([\mathrm{O}]_{\mathrm{Ti}}\right.$ (mass $\%)$ ) and $p_{\mathrm{O}_{2}}$ is expressed as follows: ${ }^{35)}$

$$
\begin{aligned}
& 1 / 2 \mathrm{O}_{2}(g)=\mathrm{O}(1 \mathrm{mass} \%, \text { in } \beta \text {-Ti }) \\
& \Delta G^{\circ}{ }_{1, \mathrm{Ti}}=-2.303 \mathrm{R} T \log \left(f_{\mathrm{O}} \cdot[\mathrm{O}]_{\mathrm{Ti}} / p_{\mathrm{O}_{2}}{ }^{1 / 2}\right) \\
& \Delta G^{\circ}{ }_{1, \mathrm{Ti}}=-583000+88.5 T(\mathrm{~J})[1173-1373 \mathrm{~K}]
\end{aligned}
$$

where $\mathrm{O}$ dissolved in $\mathrm{Ti}$ is expressed relative to the $1 \mathrm{mass} \%$ standard state; $\Delta G^{\circ}{ }_{1, \mathrm{Ti}}$ is the standard Gibbs energy of the $\mathrm{O}$ dissolution in $\mathrm{Ti} ; \mathrm{R}$ is the gas constant; $T$ is the absolute temperature; and $f_{\mathrm{O}}$ is the Henrian activity coefficient for $\mathrm{O}$ dissolved in Ti. Given that the $\mathrm{O}$ dissolved in Ti obeys Henry's law, the value of $f_{\mathrm{O}}$ is defined to be unity.

For example, when 1 mass $\%$ O (10000 ppm O) is dissolved in $\beta$-Ti at $1300 \mathrm{~K}, p_{\mathrm{O}_{2}}$ is determined to be as low as $2.5 \times$ $10^{-38} \mathrm{~atm}\left(2.5 \times 10^{-33} \mathrm{~Pa}\right)$. At such an extremely low $\mathrm{O}_{2}$ potential, direct removal of $\mathrm{O}$ from $\mathrm{Ti}$ during the sintering process is impossible in an inert gas or vacuum state. Therefore, Ti powder with low-O-concentration is greatly needed for conventional PM-Ti technologies. However, lowO-concentration Ti powder is expensive, because it is difficult to produce with high-purity using conventional technologies. 
Table 1 Previous studies of the production of sintered Ti at low-oxygen concentrations.

\begin{tabular}{|c|c|c|c|}
\hline Author, year & Method & $\begin{array}{l}\text { Initial oxygen } \\
\text { concentration } \\
\text { of Ti powder, } \\
C_{\mathrm{o}, \text { initial }} \\
(\mathrm{ppm} \mathrm{O})\end{array}$ & $\begin{array}{l}\text { Oxygen } \\
\text { concentration } \\
\text { of sintered } \mathrm{Ti} \text {, } \\
C_{\mathrm{o}, \text { sintered }} \\
(\mathrm{ppm} \mathrm{O})\end{array}$ \\
\hline 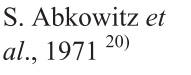 & Unknown & & 415 \\
\hline 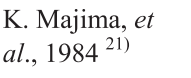 & Sintered under vacuum & 1500 & 2000 \\
\hline $\begin{array}{l}\text { K. Majima, et } \\
\text { al., } 1984^{21)}\end{array}$ & Sintering with $\mathrm{Ca}$ vapor & 1500 & 1960 \\
\hline $\begin{array}{l}\text { P.K. Tripathy, } \\
\text { et al., } 2007^{22)}\end{array}$ & $\begin{array}{l}\text { Electrochemical method } \\
\text { in } \mathrm{CaCl}_{2}(l)\end{array}$ & $\mathrm{TiO}_{2}$ & $<1500$ \\
\hline 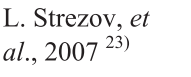 & $\begin{array}{l}\text { Electrochemical method } \\
\text { in } \mathrm{CaCl}_{2}(l)\end{array}$ & $\mathrm{TiO}_{2}$ & $<500$ \\
\hline $\begin{array}{l}\text { J.C. Choi et al., } \\
2009^{24)}\end{array}$ & $\begin{array}{l}\text { Sintering Ti powder } \\
\text { with } \mathrm{Ca} \text { under vacuum }\end{array}$ & & 7100 \\
\hline $\begin{array}{l}\text { A.T. Sidambe, } \\
\text { et al., } 2014^{25)}\end{array}$ & Sintering in Ar & 1430 & 1700 \\
\hline $\begin{array}{l}\text { S.D. Luo, et al., } \\
2013^{26)}\end{array}$ & $\begin{array}{l}\text { Microwave sintering } \\
\text { with Ti sponge }\end{array}$ & & 2100 \\
\hline $\begin{array}{l}\text { E. Carreño- } \\
\text { Morelli , } \\
\text { et al., } 2014^{27)}\end{array}$ & Sintering $\mathrm{TiH}_{2}$ powder & $\mathrm{TiH}_{2}$ & 3000 \\
\hline $\begin{array}{l}\text { J.M. Oh, et al., } \\
2016^{28)}\end{array}$ & $\begin{array}{l}\text { Sintering with } \mathrm{Ca} \text { and } \\
\mathrm{CaCl}_{2} \text { vapor }\end{array}$ & 2000 & $3000-3100$ \\
\hline $\begin{array}{l}\text { Z.Z. Fang, et } \\
\text { al., } 2017^{29)}\end{array}$ & $\begin{array}{l}\text { "Partial sintering" in } \\
\mathrm{CaCl}_{2}(l)\end{array}$ & & $<1000$ \\
\hline \multirow[t]{2}{*}{$\begin{array}{l}\text { The aim of this } \\
\text { study, } 2019\end{array}$} & $\begin{array}{l}\text { Utilizing } \mathrm{Y} / \mathrm{Y}_{2} \mathrm{O}_{3} \\
\text { equilibrium }\end{array}$ & & $200-2000$ \\
\hline & $\begin{array}{l}\text { Utilizing } \mathrm{Y} / \mathrm{YOCl} / \mathrm{YCl}_{3} \\
\text { equilibrium }\end{array}$ & & $30-60$ \\
\hline
\end{tabular}

Based on this background, many researchers have focused on using deoxidizing agents in PM-Ti. In particular, calcium (Ca) metal is well known for its strong deoxidizing capability and its high vapor pressure. For example, in 1984, Majima et al. reported a sintering method for Ti powder in $\mathrm{Ca}$ vapor, but the $\mathrm{O}$ concentration in $\mathrm{Ti}$ increased during the process. ${ }^{21)}$ Until recently, some researchers (e.g., Choi et al. and Oh et al.) had reported sintering methods for $\mathrm{Ti}$ in $\mathrm{Ca}$ vapor. ${ }^{24,28)}$ Nevertheless, the sintering methods of $\mathrm{Ti}$ using $\mathrm{Ca}$ vapor are not widely used at an industrial scale, partly because it is challenging to efficiently remove the by-products of the deoxidation reaction (e.g., $\mathrm{CaO}(s)$ ) from inside the sintered Ti body.

In molten salts, such as $\mathrm{CaCl}_{2}(l)$, which is stable at extremely low $\mathrm{O}_{2}$ potential, the solubility of the oxide ion $\left(\mathrm{O}^{2-}\right)$ is high. Thermochemical and electrochemical deoxidation processes in molten salts are widely known as efficient techniques to remove $\mathrm{O}$ from $\mathrm{Ti}$. Ca metal is widely known as an efficient deoxidizing agent for $\mathrm{Ti}$ in $\mathrm{CaCl}_{2}$, and many researchers have reported that the sintering reaction of $\mathrm{Ti}$ powders occurred in molten salt. ${ }^{28,36-43)}$ Additionally, researchers have produced sintered $\mathrm{Ti}$ from $\mathrm{TiO}_{2}$ powder using an electrochemical process with molten salt. In 2007, Tripathy et al. produced sintered Ti with 1500 ppm O or less by applying a voltage between a $\mathrm{TiO}_{2}$ cathode and a carbon anode in $\mathrm{CaCl}_{2}$ (Fray-Farthing-Chen Cambridge method, FFC method). ${ }^{22,44)}$ In the same year, Strezov et al. ${ }^{23)}$ reported in a patent that they had produced sintered Ti with $500 \mathrm{ppm}$ $\mathrm{O}$ or less using the FFC method. More recently, $\mathrm{Hu}$ et al. produced golf-club-sized sintered $\mathrm{Ti}$ using the FFC method. ${ }^{30,31)}$

To the best of our knowledge, there has been no report about producing sintered Ti with reliably lower than $400 \mathrm{ppm}$ $\mathrm{O}$, or of precisely controlling the $\mathrm{O}$ concentration in $\mathrm{Ti}$ in the range of 100-2000 ppm O. In conventional PM-Ti technologies, $\mathrm{O}$ concentrations in Ti increase during the sintering process and expensive $\mathrm{Ti}$ powder with low-O concentration is necessary to produce reliable $\mathrm{Ti}$ products. To solve this problem for PM-Ti, we focused on developing a new sintering process that controls the $\mathrm{O}$ concentration in $\mathrm{Ti}$ using the deoxidation techniques of pyrometallurgy.

In the past, the amounts of rare-earth (RE) metals production were small, and it was not economical to use $\mathrm{RE}$ metals for the deoxidation of $\mathrm{Ti}$ on an industrial scale. However, the demand for RE magnets, especially $\mathrm{Nd}-\mathrm{Fe}-\mathrm{B}$ magnets doped with Dy, has rapidly increased in recent years. ${ }^{45)}$ Some RE metals, including Y, La, Ce, and Ho are produced as by-products of $\mathrm{Nd}$ and Dy. Industrially, the applications of these RE metals are limited and their demands are not expected to increase. Therefore, there will be a chronic oversupply of these RE metals in the future. Thus, the use of $\mathrm{Y}, \mathrm{La}, \mathrm{Ce}$, and Ho metals for new deoxidation technology in PM-Ti ensures efficient utilization of natural resources and can be justified economically.

In PM-Ti fields, some researchers have reported that the mechanical properties of sintered Ti could be improved with small additions of RE compounds (RE oxides, RE hydrides, RE borides, etc.). ${ }^{46-48)}$ Especially, the mechanical strengthening effect due to oxide particle distribution by internal oxidation of RE elements is actively studied.

In contrast, we focused on the deoxidation of $\mathrm{Ti}$ by dissolving $\mathrm{O}$ in molten salt using $\mathrm{RE}$ metals. The deoxidation limits in the $\mathrm{RE} / \mathrm{RE}_{2} \mathrm{O}_{3}$ equilibrium for bulk $\mathrm{Ti}$ have been experimentally demonstrated. ${ }^{49-53)}$ Specifically, Y is considered to have the strongest deoxidizing capability in the RE/ $\mathrm{RE}_{2} \mathrm{O}_{3}$ equilibrium in all rare earth metals. For example, when $a_{\mathrm{Y}}=1$ and $a_{\mathrm{Y}_{2} \mathrm{O}_{3}}=1$ at $1300 \mathrm{~K}$, the $\mathrm{O}$ concentration in bulk Ti decreases to approximately $100-200 \mathrm{ppm} \mathrm{O}$ in the $\mathrm{Y} / \mathrm{Y}_{2} \mathrm{O}_{3}$ equilibrium. Just recently, we experimentally demonstrated that the $\mathrm{O}$ concentration in $\mathrm{Ti}$ could be decreased to $30-60 \mathrm{ppm} \mathrm{O}$ in the $\mathrm{Y} / \mathrm{YOCl} / \mathrm{YCl}_{3}$ equilibrium at $1300 \mathrm{~K} .{ }^{53)}$ However, there has been no research on the behavior of Ti powder at such an extremely low $\mathrm{O}_{2}$ potential $\left(p_{\mathrm{O}_{2}}<2.5 \times 10^{-42} \mathrm{~atm}\right.$ at $1300 \mathrm{~K}, \mathrm{O}$ concentration in $\mathrm{Ti}<$ 100 ppm O).

In this study, we developed a new sintering process that can remove $\mathrm{O}$ from Ti using $\mathrm{Y}$ metal as the deoxidizing agent in molten salt. Our goal is to demonstrate a new sintering process in which the $\mathrm{O}$ concentration in $\mathrm{Ti}$ can be controlled within the range of approximately 30-2000 ppm O (Table 1).

\section{Thermodynamic Consideration}

To design a new deoxidation method using molten salt, we determined the deoxidation reaction and the molten salt 
$\mathrm{M}-\mathrm{Cl}-\mathrm{O}$ system at $1300 \mathrm{~K}(\mathrm{M}=\mathrm{Li}, \mathrm{Na}, \mathrm{K}, \mathrm{Ca}, \mathrm{Mg}, \mathrm{Y})$

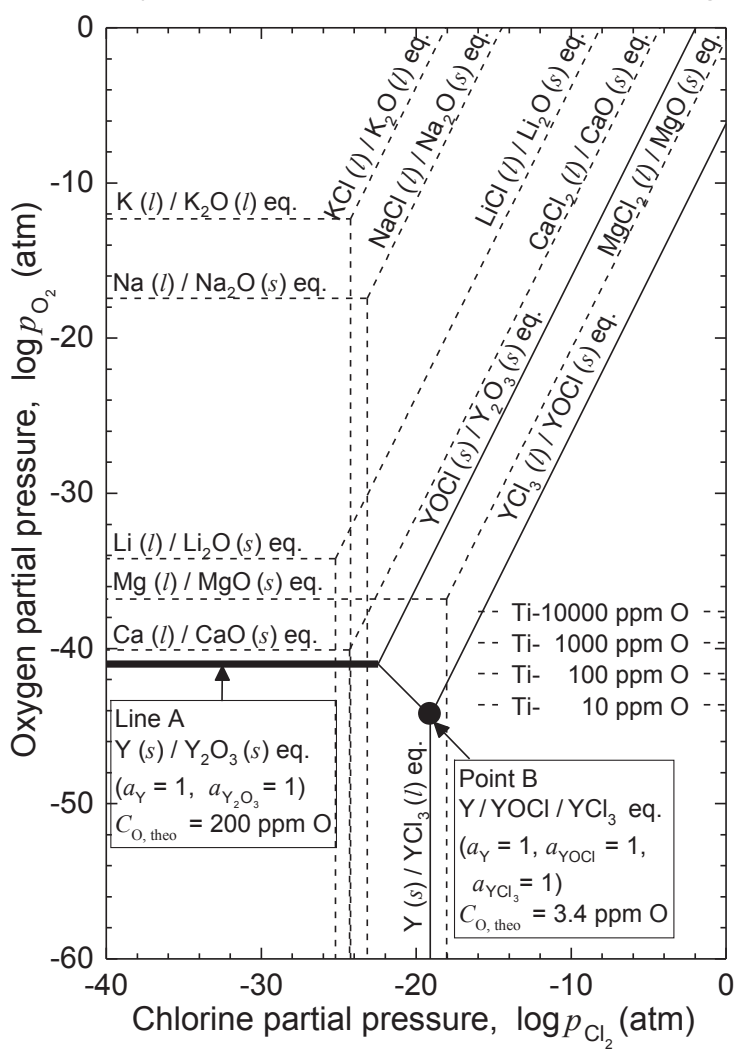

Fig. 1 Phase stability diagram for the $\mathrm{M}-\mathrm{Cl}-\mathrm{O}$ system $(\mathrm{M}=\mathrm{Li}, \mathrm{Na}, \mathrm{K}$, $\mathrm{Mg}, \mathrm{Ca}$ and $\mathrm{Y}$ ) at $1300 \mathrm{~K} .^{15,54,55)}$

suitable to control the $\mathrm{O}$ concentration in $\mathrm{Ti}$ using a thermodynamic consideration. We set the experimental temperature to $1300 \mathrm{~K}$, because this temperature is experimentally known to facilitate the deoxidation of $\mathrm{Ti}$ in molten salt.

In the $\mathrm{Y}-\mathrm{O}-\mathrm{Cl}$ system at $1300 \mathrm{~K}, \mathrm{Y}_{2} \mathrm{O}_{3}(s), \mathrm{YOCl}(s)$, and $\mathrm{YCl}_{3}(l)$ are reported as stable compounds. Figure 1 shows a phase stability diagram produced from a plot of the partial pressure of $\mathrm{Cl}_{2}, p_{\mathrm{Cl}_{2}}$, vs. the partial pressure of $\mathrm{O}_{2}, p_{\mathrm{O}_{2}}$, for the $\mathrm{M}-\mathrm{O}-\mathrm{Cl}$ system $(\mathrm{M}=\mathrm{Li}, \mathrm{Na}, \mathrm{K}, \mathrm{Ca}, \mathrm{Mg}, \mathrm{Y})$ at $1300 \mathrm{~K}$. Table 2 shows the thermodynamic data used to draw Fig. $1 .{ }^{35,54,55)}$ The relationship between the $\mathrm{O}$ concentration in Ti and $p_{\mathrm{O}_{2}}$ based on equilibrium theory, is also expressed in Fig. 1 using eqs. (1)-(3).

As shown in Fig. $1, \mathrm{LiCl}, \mathrm{NaCl}, \mathrm{KCl}$, and $\mathrm{CaCl}_{2}$ have regions coexisting with the $\mathrm{Y} / \mathrm{Y}_{2} \mathrm{O}_{3}$ equilibrium (Line A) and the $\mathrm{Y} / \mathrm{YOCl} / \mathrm{YCl}_{3}$ equilibrium (Point $\mathrm{B}$ ). Thus, in molten $\mathrm{LiCl}, \mathrm{NaCl}, \mathrm{KCl}$, and $\mathrm{CaCl}_{2}, \mathrm{Y}$ metal is stable and the following deoxidation reactions proceed at $1300 \mathrm{~K}$. In $\mathrm{MgCl}_{2}, \mathrm{Y}$ metal is unstable.

$$
\begin{aligned}
& \mathrm{O}(\text { in } \mathrm{Ti})+2 / 3 \mathrm{Y}(s)=1 / 3 \quad \mathrm{Y}_{2} \mathrm{O}_{3}(s) \\
& \Delta G_{\mathrm{r}, \text { deox [4] }}^{\circ}=1 / 3 \Delta G^{\circ}{ }_{\mathrm{f}, \mathrm{Y}_{2} \mathrm{O}_{3}}-\Delta G^{\circ}{ }_{1, \mathrm{Ti}} \\
& {[\mathrm{O}]_{\mathrm{Ti}[4]}=\left(a_{\mathrm{Y}_{2} \mathrm{O}_{3}}{ }^{1 / 3} / a_{\mathrm{Y}}{ }^{2 / 3}\right) \exp \left(\Delta G_{\mathrm{r} \text {, deox [4] }}^{\circ} / \mathrm{R} T\right)} \\
& C_{\mathrm{O} \text {, theo [4] }}=200\left(a_{\mathrm{Y}_{2} \mathrm{O}_{3}}{ }^{1 / 3} / a_{\mathrm{Y}}{ }^{2 / 3}\right)(\text { mass ppm O) } \\
& \mathrm{O}(\text { in Ti })+2 / 3 \mathrm{Y}(s)+1 / 3 \mathrm{YCl}_{3}(l)=\mathrm{YOCl}(s) \\
& \Delta G_{\mathrm{r}, \text { deox }[8]}^{\circ}=\Delta G_{\mathrm{f}, \mathrm{YOCl}}^{\circ}-1 / 3 \Delta G_{\mathrm{f}, \mathrm{YCl}_{3}}^{\circ}-\Delta G^{\circ}{ }_{1, \mathrm{Ti}}
\end{aligned}
$$

Table 2 Standard Gibbs free energy of formation at $1300 \mathrm{~K}$ used in Fig. 1 drawing.

\begin{tabular}{lcc}
\hline Species, $i$ & $\begin{array}{l}\text { Standard Gibbs energy } \\
\text { of formation, } \Delta G_{\mathrm{f}, i}^{\circ}\end{array}$ & Ref. \\
& $/ \mathrm{kJ} \cdot \mathrm{mol}^{-1}$ at $1300 \mathrm{~K}$ & \\
\hline $\mathrm{O}(1 \mathrm{mass} \%$, in $\beta$-Ti) & -468 & 15 \\
\hline $\mathrm{LiCl}(l)$ & -314 & 54 \\
$\mathrm{Li}_{2} \mathrm{O}(\mathrm{s})$ & -426 & 54 \\
\hline $\mathrm{NaCl}(l)$ & -288 & 54 \\
$\mathrm{Na}_{2} \mathrm{O}(s)$ & -216 & 54 \\
\hline $\mathrm{KCl}(l)$ & -302 & 54 \\
$\mathrm{~K}_{2} \mathrm{O}(l)$ & -153 & 54 \\
\hline $\mathrm{MgCl}_{2}(l)$ & -449 & 54 \\
$\mathrm{MgO}(s)$ & -458 & 54 \\
\hline $\mathrm{CaCl}_{2}(l)$ & -605 & 54 \\
$\mathrm{CaO}_{(s)}(s)$ & -499 & 54 \\
\hline $\mathrm{Y}_{2} \mathrm{O}_{3}(s)$ & -1530 & 54 \\
$\mathrm{YCl}_{3}(l)$ & -713 & 54 \\
$\mathrm{YOCl}(s)$ & -790 & 55 \\
\hline
\end{tabular}

$$
\begin{aligned}
& {[\mathrm{O}]_{\mathrm{Ti}[8]}=\left(a_{\mathrm{YOCl}} /\left(a_{\mathrm{Y}}{ }^{2 / 3} \cdot a_{\mathrm{YCl}_{3}}{ }^{1 / 3}\right)\right) \exp \left(\Delta G_{\mathrm{r}, \operatorname{deox}[8]}^{\circ} / \mathrm{R} T\right)} \\
& C_{\mathrm{O} \text {, theo [8] }}=3.4\left(a_{\mathrm{YOCl}} /\left(a_{\mathrm{Y}}{ }^{2 / 3} \cdot a_{\mathrm{YCl}_{3}}{ }^{1 / 3}\right)\right)(\text { mass ppm O) }
\end{aligned}
$$

where $\Delta G_{\mathrm{f}, i}^{\circ}$ is the standard Gibbs free energy of formation for each compound; $a_{i}$ is the activity of each chemical species; and $C_{\mathrm{O} \text {, theo }}$ is the $\mathrm{O}$ concentration in $\mathrm{Ti}$ (mass ppm O).

Conversely, when $\mathrm{Y}$ metal is placed in molten $\mathrm{MgCl}_{2}$, the following displacement reaction occurs:

$$
3 \mathrm{MgCl}_{2}(l)+2 \mathrm{Y}(s) \rightarrow 2 \mathrm{YCl}_{3}(l)+3 \mathrm{Mg}(l)
$$

As long as $\mathrm{MgCl}_{2}$ exists in the system, Y metal induces the displacement reaction with $\mathrm{MgCl}_{2}$ (eq. (12)). In this study, $\mathrm{MgCl}_{2}$ was excluded from the flux candidates for the sintering process in order to use Y metal as the deoxidizing agent.

There is a possibility that the sintering $\mathrm{Ti}$ samples were contaminated by $\mathrm{Y}$ and other elements. For example, $\mathrm{Y}$ has a very small solubility in $\mathrm{Ti}$ (approximately $0.2 \mathrm{~mol} \%$ at $1300 \mathrm{~K}$ ) based on available thermodynamic data in the literature. ${ }^{56)}$ This study is a proof-of-concept of the new sintering process with deoxidation, and the contamination of such elements should be investigated in detail as future works.

Figure 2 shows the relationship between $[\mathrm{O}]_{\mathrm{Ti}}$ and $a_{\mathrm{Y}}$ in the $\mathrm{Y} / \mathrm{Y}_{2} \mathrm{O}_{3}$ and $\mathrm{Y} / \mathrm{YOCl} / \mathrm{YCl}_{3}$ equilibria at $1300 \mathrm{~K}$. In this study, the $\mathrm{Y} / \mathrm{Y}_{2} \mathrm{O}_{3}$ equilibrium was employed to control the $\mathrm{O}$ concentration in the range of 200-2000 ppm $\mathrm{O}$ with varying $a_{\mathrm{Y}}$ in eutectic $\mathrm{NaCl}-\mathrm{KCl}(l)(50 \mathrm{~mol} \% \mathrm{NaCl}-\mathrm{KCl})$. Additionally, the $\mathrm{Y} / \mathrm{YOCl} / \mathrm{YCl}_{3}$ equilibrium was employed to reduce the $\mathrm{O}$ concentration in $\mathrm{Ti}$ to $30-60 \mathrm{ppm} \mathrm{O}$ in 


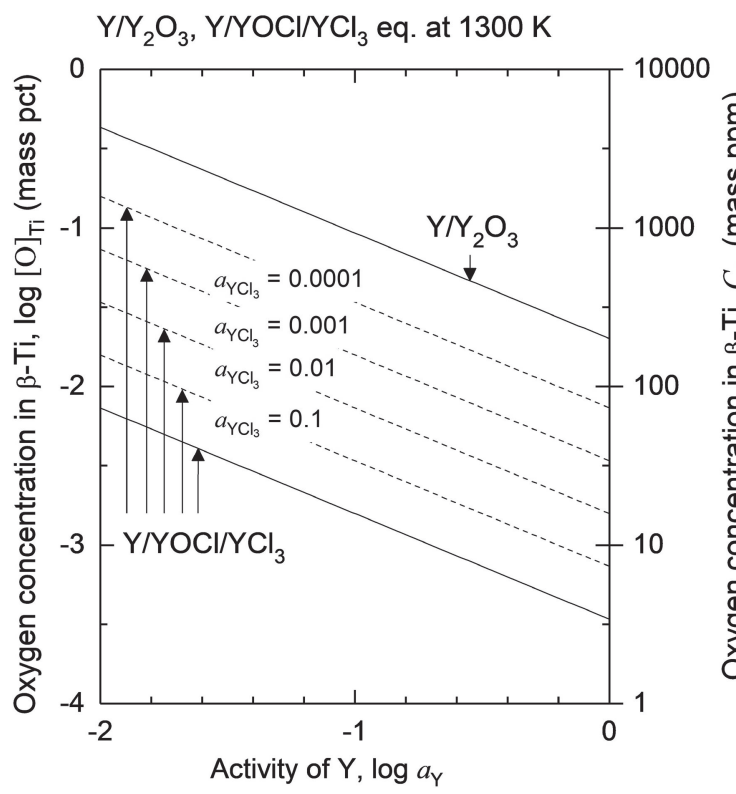

Fig. 2 Relationship between oxygen concentration in $\beta$-Ti determined by $\mathrm{Y} / \mathrm{Y}_{2} \mathrm{O}_{3}$ and $\mathrm{Y} / \mathrm{YOCl} / \mathrm{YCl}_{3}$ equilibria, and activity of yttrium $\left(a_{\mathrm{Y}}\right)$, varying $a_{\mathrm{YCl}_{3}} \cdot{ }^{15,54,55)}$

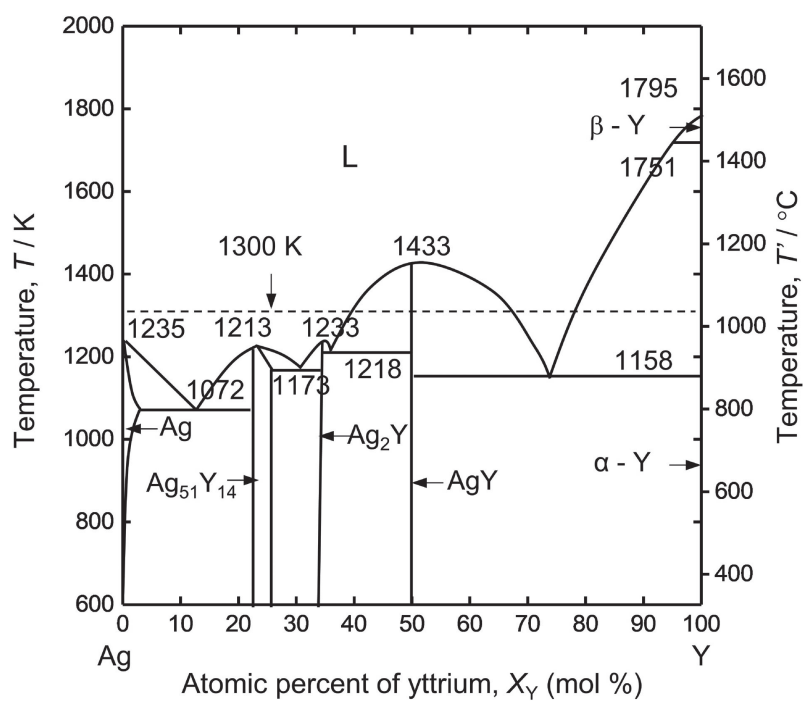

Fig. 3 Y-Ag binary phase diagram. ${ }^{56)}$

$\mathrm{YCl}_{3}(l)$. The difference between the calculated value ( $3.4 \mathrm{ppm} \mathrm{O}$ ) in eq. (11) of the $\mathrm{O}$ concentration in $\mathrm{Ti}$ and the experimental value (30-60 ppm O) was caused by the inaccuracy of $\Delta G_{\mathrm{f}, \mathrm{YOCl}}^{\circ}$ and $\Delta G_{\mathrm{f}, \mathrm{YCl}_{3}}$ in the literature. ${ }^{53)}$

To vary $a_{\mathrm{Y}}$ in the $\mathrm{Y} / \mathrm{Y}_{2} \mathrm{O}_{3}$ equilibrium and to control $p_{\mathrm{O}_{2}}$ in the system, $\mathrm{Y}-\mathrm{Ag}$ alloy was used in this study. Figure 3 shows the binary diagram of the $\mathrm{Y}-\mathrm{Ag}$ system, and Fig. 4 shows the relationship between the mole fraction of $\mathrm{Y}, X_{\mathrm{Y}}$, in the $\mathrm{Y}-\mathrm{Ag}$ alloy and $a_{\mathrm{Y}}$ at $1346 \mathrm{~K} .{ }^{57)}$ In this study, the relationship between $X_{\mathrm{Y}}$ and $a_{\mathrm{Y}}$ at $1346 \mathrm{~K}$ was applied as an approximation at $1300 \mathrm{~K}$.

Through the thermodynamic considerations above, a new sintering process with the deoxidation of Ti using Y metal as the deoxidizing agent was designed, as shown in Fig. 5. In this process, with electron transfer in the conductive plate, $\mathrm{O}$ in $\mathrm{Ti}$ and $\mathrm{Y}$ dissolve into $\mathrm{NaCl}-\mathrm{KCl}$ as oxide ion $\left(\mathrm{O}^{2-}\right)$ and yttrium ion $\left(\mathrm{Y}^{3+}\right)$, respectively. These ions produce $\mathrm{Y}_{2} \mathrm{O}_{3}(s)$

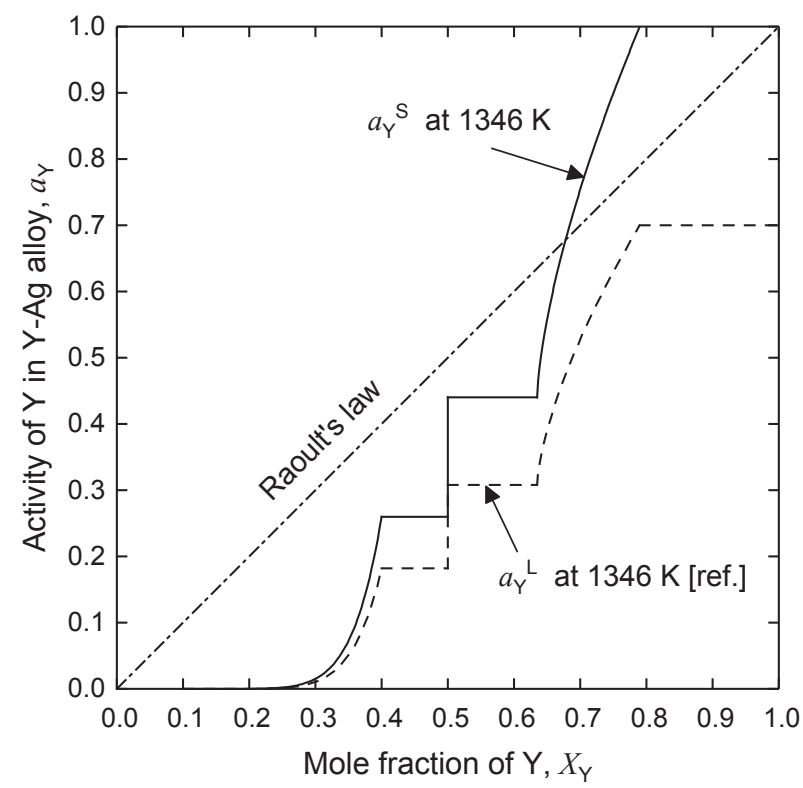

Fig. 4 Relationship between mole fraction of yttrium and activity of yttrium in $\mathrm{Y}-\mathrm{Ag}$ system at $1346 \mathrm{~K}^{56}$ )

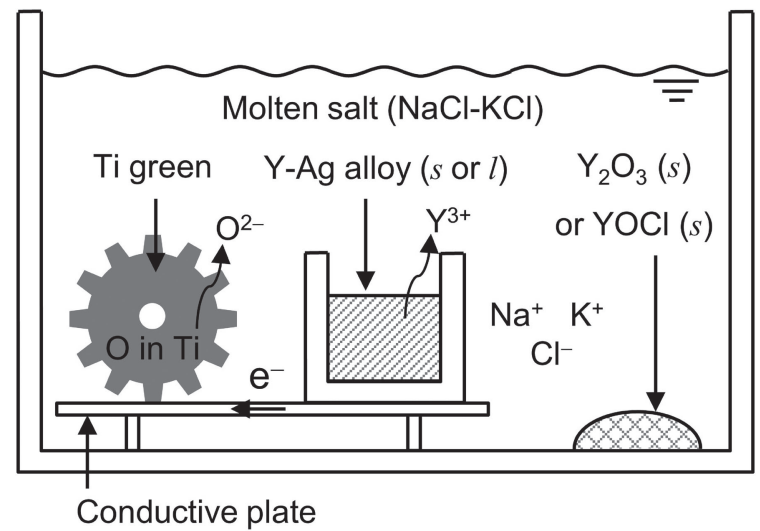

Fig. 5 Schematic illustration of the new sintering process developed in this study showing control of oxygen concentration in Ti.

or $\mathrm{YOCl}(s)$ and the $\mathrm{O}$ concentration in $\mathrm{Ti}$ decreased following the reactions (4) and (8).

\section{Experimental Procedure}

Figure 6(a) shows a schematic of the experimental apparatus in a Ti crucible. Bulk Ti samples (approximately $0.1 \mathrm{~g}$ each) and a Ti pellet were placed in the Ti crucible, as shown in Fig. 6(a). The Ti crucibles were placed with $\mathrm{Ti}$ sponge (getter) in a stainless-steel container, which was completely sealed via welding. The Ti samples, which were used for measuring $\mathrm{O}$ concentration, were cubes having 2$3 \mathrm{~mm}$ sides (Ti-2B, ca. $230 \mathrm{ppm} \mathrm{O}$ ), $1.2 \mathrm{~mm}$ diameter wires (Ti-1.2U, ca. $1200 \mathrm{ppm} \mathrm{O}$ ), and $2 \mathrm{~mm}$ diameter wires (Ti-2L, ca. $1200 \mathrm{ppm} \mathrm{O}$ ). Ti pellets were made from hydridedehydride Ti powder (press pressure: $\sim 500 \mathrm{MPa}$ ). Detailed information on the samples used in the experiments is shown in Table 3.

The initial amounts of samples and reagents in each lot are shown in Tables 4 and 5. In the experiments of the $\mathrm{Y} / \mathrm{Y}_{2} \mathrm{O}_{3}$ equilibrium, approximately $1 \mathrm{~g}$ of $\mathrm{Y}_{2} \mathrm{O}_{3}$ was added into the 
(a)

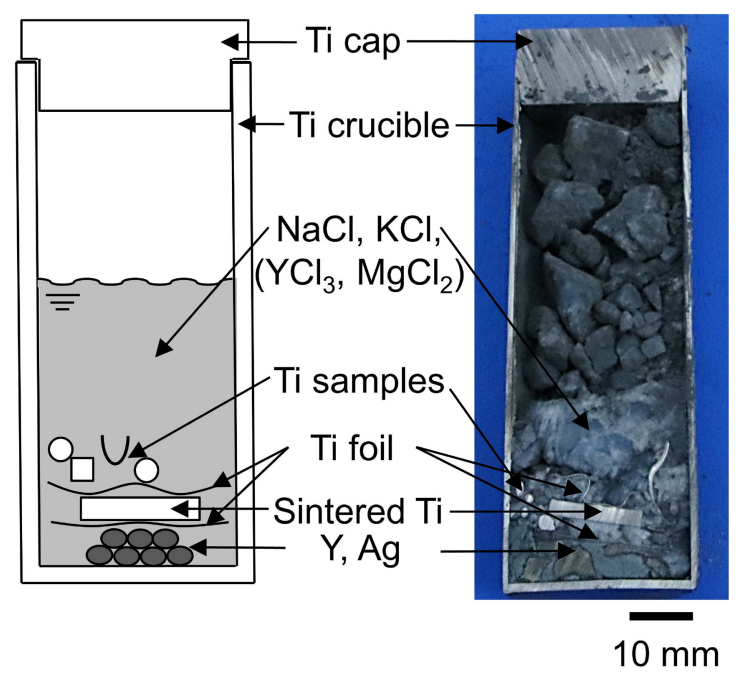

Fig. 6 (a) Schematic illustration and (b) photograph (181001-lot.3-1) of the Ti crucible.

Table 3 Materials and reagents used in the experiments.

\begin{tabular}{|c|c|c|c|}
\hline Materials & Form & Purity / grade & Supplier / note \\
\hline \multirow[t]{3}{*}{$\begin{array}{l}\mathrm{Ti} \\
\text { crucible }\end{array}$} & $\begin{array}{l}25.4 \mathrm{~mm} \\
\text { in diameter }\end{array}$ & $\mathrm{CP}-\mathrm{Ti}^{\mathrm{a}}$ & $\begin{array}{l}\text { Shinkinzoku Industry } \\
\text { Co., Ltd. }\end{array}$ \\
\hline & $1 \mathrm{~mm}$ in thickness & & \\
\hline & $80 \mathrm{~mm}$ in height & & \\
\hline Ti cap & & $\mathrm{CP}-\mathrm{Ti}^{\mathrm{a}}$ & $\begin{array}{l}\text { Shinkinzoku Industry } \\
\text { Co., Ltd. }\end{array}$ \\
\hline Ti foil & $\begin{array}{l}0.1 \mathrm{~mm} \\
\text { in thickness }\end{array}$ & $\mathrm{CP}-\mathrm{Ti}^{\mathrm{a}}$ & $\begin{array}{l}\text { Shinkinzoku Industry } \\
\text { Co., Ltd. }\end{array}$ \\
\hline Ti-2B & $\begin{array}{l}\text { cube with } 2 \mathrm{~mm} \\
\text { in length of side }\end{array}$ & $\sim 230$ mass ppm $\mathrm{O}$ & $\begin{array}{l}\text { High purity } \mathrm{Ti} \\
\text { sponge, } \\
\text { electron-beam melted }\end{array}$ \\
\hline $\mathrm{Ti}-1.2 \mathrm{U}$ & $\begin{array}{l}\text { wire with } 1.2 \\
\mathrm{~mm} \text { in diameter }\end{array}$ & $\sim 1200$ mass ppm O & $\begin{array}{l}\text { Shinkinzoku Industry } \\
\text { Co., Ltd. }\end{array}$ \\
\hline Ti-2L & $\begin{array}{l}\text { wire with } 2 \mathrm{~mm} \\
\text { in diameter }\end{array}$ & $\sim 1200$ mass ppm O & $\begin{array}{l}\text { Shinkinzoku Industry } \\
\text { Co., Ltd. }\end{array}$ \\
\hline $\mathrm{Ti}$ & sponge & $\geq 97.0 \%$ & $\begin{array}{l}\text { Toho Titanium Co., } \\
\text { Ltd. }\end{array}$ \\
\hline \multirow[t]{3}{*}{$\mathrm{Ti}$} & HDH Powder, & $\geq 99.4 \%$ & Osaka Titanium \\
\hline & irregular shapes & $\begin{array}{l}<3500 \mathrm{ppm} \mathrm{O}^{<} \\
<300 \mathrm{ppm} \mathrm{N}\end{array}$ & Technologies Co., \\
\hline & $\begin{array}{l}\text { particle size: } \\
<45 \mu \mathrm{m}\end{array}$ & & \\
\hline Y & shot & $\geq 99 \%$ & Santoku Co., Ltd. \\
\hline $\mathrm{Ag}$ & shot & $\geq 99.99 \%$ & $\begin{array}{l}\text { Ishifuku Kinzoku Co., } \\
\text { Ltd. }\end{array}$ \\
\hline $\mathrm{YCl}_{3}$ & powder & $\geq 99.9 \%$, anhydrous & Alfa Aesar Co., Ltd. \\
\hline $\mathrm{Y}_{2} \mathrm{O}_{3}$ & powder & $\geq 99.9 \%$ & $\begin{array}{l}\text { Shin-Etsu Chemical } \\
\text { Co., Ltd. }\end{array}$ \\
\hline $\mathrm{NaCl}$ & powder & $\geq 99 \%$ & $\begin{array}{l}\text { Wako Industry Co., } \\
\text { Ltd. }\end{array}$ \\
\hline $\mathrm{KCl}$ & powder & $\geq 99 \%$ & $\begin{array}{l}\text { Wako Industry Co., } \\
\text { Ltd. }\end{array}$ \\
\hline $\begin{array}{l}\text { Stainless } \\
\text { steel } \\
\text { crucible } \\
\text { (tube and } \\
\text { plate) }\end{array}$ & & $\begin{array}{l}\text { SUS 316, } \\
\text { Ni: } 10-14 \% \\
\text { Cr: } 16-18 \% \\
\text { Mo: } 2-3 \% \\
\text { Fe: balanced }\end{array}$ & $\begin{array}{l}\text { Azabu Industry Co., } \\
\text { Ltd. }\end{array}$ \\
\hline
\end{tabular}

initial feed to maintain $a_{\mathrm{Y}_{2} \mathrm{O}_{3}}$ at unity. The stainless-steel container was placed in a box-type electric furnace and held at $1300 \mathrm{~K}$ for $173 \mathrm{ks}$. The holding time was determined based on the diffusion coefficient of $\mathrm{O}$ in $\mathrm{Ti}$ at $1300 \mathrm{~K}^{58)}$ and an
Table 4 Initial amounts of samples and reagents in the Ti crucible for the experiment utilizing the $\mathrm{Y} / \mathrm{Y}_{2} \mathrm{O}_{3}$ equilibrium.

\begin{tabular}{|c|c|c|c|c|c|c|c|}
\hline \multirow[t]{2}{*}{ Exp. no. } & \multirow[t]{2}{*}{$a_{\mathrm{Y}}^{\mathrm{a}, \mathrm{b}, \mathrm{c}}$} & \multicolumn{5}{|c|}{$\begin{array}{l}\text { Initial amount of samples in the titanium } \\
\text { crucible, } \mathrm{m} / \mathrm{g}(\mathrm{n} / \mathrm{mol})\end{array}$} & \multirow[t]{2}{*}{$\begin{array}{l}C_{\mathrm{O}, \text { theo }} \\
(\mathrm{ppm} \mathrm{O})^{\mathrm{d}}\end{array}$} \\
\hline & & $\mathrm{NaCl}$ & $\mathrm{KCl}$ & $\mathrm{Y}$ & $\mathrm{Ag}$ & $\mathrm{Y}_{2} \mathrm{O}_{3}$ & \\
\hline $\begin{array}{l}81001- \\
t .3-1^{\mathrm{e}}\end{array}$ & 1 & $\begin{array}{l}16.22 \\
(0.278)\end{array}$ & $\begin{array}{l}20.68 \\
(0.278)\end{array}$ & $\begin{array}{l}4.42 \\
(0.0497)\end{array}$ & & $\begin{array}{l}1.13 \\
(0.00500)\end{array}$ & 200 \\
\hline $\begin{array}{l}81212- \\
t .4-1^{\mathrm{e}}\end{array}$ & 1 & $\begin{array}{l}14.72 \\
(0.252)\end{array}$ & $\begin{array}{l}18.78 \\
(0.252)\end{array}$ & $\begin{array}{l}5.33 \\
(0.0599)\end{array}$ & & $\begin{array}{l}1.16 \\
(0.00514)\end{array}$ & 200 \\
\hline 310 & & & & $\begin{array}{l}5.33 \\
(0.0599)\end{array}$ & $\begin{array}{l}4.33 \\
(0.0401)\end{array}$ & $\begin{array}{l}1.13 \\
(0.00500)\end{array}$ & 350 \\
\hline 812 & 0.44 & & & $\begin{array}{r}5.33 \\
(0.05\end{array}$ & $\begin{array}{l}4.32 \\
(0.0401)\end{array}$ & $\begin{array}{l}1.15 \\
(0.00509)\end{array}$ & 350 \\
\hline $\begin{array}{l}81( \\
\text { t. } 3\end{array}$ & 0.26 & $5)$ & $\begin{array}{l}18.2 \\
(0.2\end{array}$ & $\begin{array}{r}4.0 \\
(0.0\end{array}$ & $\begin{array}{l}5.93 \\
(0.0550)\end{array}$ & $\begin{array}{r}1.1 \\
(0.0\end{array}$ & 490 \\
\hline $\begin{array}{l}812 \\
\text { ot.4- }\end{array}$ & 0.26 & & $\begin{array}{l}17.32 \\
(0.232)\end{array}$ & $\begin{array}{l}4.00 \\
(0.0450)\end{array}$ & $\begin{array}{l}5.93 \\
(0.0550)\end{array}$ & $\begin{array}{l}1.13 \\
(0.00500)\end{array}$ & 490 \\
\hline $\begin{array}{l}181001- \\
\text { ot.3-4 }\end{array}$ & 0.09 & $\begin{array}{l}12.09 \\
(0.207)\end{array}$ & $\begin{array}{l}15.43 \\
(0.207)\end{array}$ & $\begin{array}{l}3.11 \\
(0.0350)\end{array}$ & $\begin{array}{l}7.01 \\
(0.0650)\end{array}$ & $\begin{array}{l}1.13 \\
(0.00500)\end{array}$ & 1000 \\
\hline $\begin{array}{l}\text { 181212- } \\
\text { lot.4-4 }\end{array}$ & 0.09 & $\begin{array}{l}16.98 \\
(0.291)\end{array}$ & $\begin{array}{l}21.66 \\
(0.291)\end{array}$ & $\begin{array}{l}3.11 \\
(0.0350)\end{array}$ & $\begin{array}{l}7.01 \\
(0.0650)\end{array}$ & $\begin{array}{l}1.13 \\
(0.00500)\end{array}$ & 1000 \\
\hline 181001- & 0.03 & $\begin{array}{l}13.20 \\
(0.226)\end{array}$ & $\begin{array}{l}16.84 \\
(0.226)\end{array}$ & $\begin{array}{l}2.22 \\
(0.0250)\end{array}$ & $\begin{array}{l}8.09 \\
(0.0750)\end{array}$ & $\begin{array}{l}1.13 \\
(0.00500)\end{array}$ & 2000 \\
\hline $\begin{array}{l}\text { 181212- } \\
\text { lot.4-5 }\end{array}$ & 0.03 & $\begin{array}{l}16.76 \\
(0.287)\end{array}$ & $\begin{array}{l}21.39 \\
(0.287)\end{array}$ & $\begin{array}{l}2.22 \\
(0.0250)\end{array}$ & $\begin{array}{l}8.09 \\
(0.0750)\end{array}$ & $\begin{array}{l}1.13 \\
(0.00500)\end{array}$ & 2000 \\
\hline
\end{tabular}

Caption:

a: Activity of $\mathrm{Y}(s)$

b: Calculated from the initial amount of the samples using the ref. 56

c: As shown in Figure 5, the activity of $\mathrm{Y}$ in the $\mathrm{Y}-\mathrm{Ag}$ system has two certain

values $\left(a_{\mathrm{Y}}=0.44,0.26\right)$. Also, we set the activities for producing sintered $\mathrm{Ti}$ at 1000 and $2000 \mathrm{ppm} \mathrm{O}$

$\mathrm{d}$ : Theoretical deoxidation limit of $\mathrm{Ti}$.

e: These values are reprinted from ref. 53 .

Table 5 Initial amounts of samples and reagents in the Ti crucible for the experiment utilizing the $\mathrm{Y} / \mathrm{YOCl} / \mathrm{YCl}_{3}$ eq. and the results of the oxygen concentration of $\mathrm{Ti}$ samples after the experiments.

\begin{tabular}{|c|c|c|c|}
\hline \multirow[t]{2}{*}{ Exp. no. } & \multicolumn{2}{|c|}{$\begin{array}{l}\text { Initial amount of samples } \\
\text { in the titanium crucible, } \\
\mathrm{m} / \mathrm{g}(\mathrm{n} / \mathrm{mol})\end{array}$} & \multirow[t]{2}{*}{$\begin{array}{l}\text { Oxygen concentration } \\
\text { after exp., } \\
C_{\mathrm{O}}{ }^{\mathrm{a}}(\mathrm{ppm} \mathrm{O})\end{array}$} \\
\hline & $\mathrm{Y}$ & $\mathrm{YCl}_{3}$ & \\
\hline $\begin{array}{l}190315- \\
\text { lot.6-1 }\end{array}$ & $\begin{array}{l}2.83 \\
(0.0318)\end{array}$ & $\begin{array}{l}21.69 \\
(0.111)\end{array}$ & $30-60$ \\
\hline
\end{tabular}

\section{Caption:}

a: Reported in our previous paper (ref. 53). Inert gas fusion method was used to detect oxygen (TC-600, LECO Corporation)

assumption of the time required to obtain a homogeneous distribution of $\mathrm{O}$ dissolved in Ti.

After holding the stainless-steel container at $1300 \mathrm{~K}$, the container was quenched in water. Figure 6(b) shows a crosssection of the Ti crucible after the experiment. The Ti sample for measuring $\mathrm{O}$ concentration was chemically polished with a 1:4:10 mixture of $\mathrm{HF}-\mathrm{HNO}_{3}-\mathrm{H}_{2} \mathrm{O}$, which was sufficient to remove impurities on the surface. It was then rinsed with distilled water and alcohol before drying. The $\mathrm{O}$ concentrations in the Ti sample was analyzed by inert gas fusion analysis (TC-600, LECO Corporation). Detailed analysis conditions are shown in Table 6.

After the experiment, salts attached to the $\mathrm{Ti}$ pellet were removed using acetic acid. Then, the surface of the Ti pellet was physically polished using a buffing grinder (\# 120, \# 1000, and \# 2000) and chemically polished with HF- 
Table 6 Results of oxygen and nitrogen analyses of Ti samples in the experiment utlizing $\mathrm{Y} / \mathrm{Y}_{2} \mathrm{O}_{3}$ equilibrium. $^{\mathrm{a}}$

\begin{tabular}{|c|c|c|c|c|c|c|}
\hline \multirow[t]{2}{*}{ Exp. no. } & \multirow[t]{2}{*}{$a_{\mathrm{Y}}{ }^{\mathrm{b}}$} & \multirow[t]{2}{*}{$\begin{array}{l}\text { Types of } \\
\text { Ti samples }\end{array}$} & \multicolumn{2}{|c|}{$\begin{array}{l}\text { Oxygen } \\
\text { concentration, } \\
C_{\mathrm{O}}(\mathrm{ppm} \mathrm{O})\end{array}$} & \multirow[t]{2}{*}{$\begin{array}{l}\text { Analyzed } \\
\text { error, } \\
\varepsilon_{0}(\%)\end{array}$} & \multirow[t]{2}{*}{$\begin{array}{l}C_{\mathrm{O}, \text { theo }} \\
(\mathrm{ppm} \mathrm{O})^{\mathrm{c}}\end{array}$} \\
\hline & & & $\begin{array}{l}\text { Initial, } \\
C_{\mathrm{O}, \text { initial }}\end{array}$ & $\begin{array}{l}\text { After exp., } \\
C_{\mathrm{O}, \text { affer }}\end{array}$ & & \\
\hline $\begin{array}{l}181001- \\
\operatorname{lot}^{2} 3-1^{\mathrm{d}, \mathrm{e}}\end{array}$ & 1 & $\begin{array}{l}2 \mathrm{~L}^{\mathrm{g}} \\
2 \mathrm{~B} \\
2 \mathrm{~B}\end{array}$ & $\begin{array}{r}1200 \\
230 \\
230\end{array}$ & $\begin{array}{l}120 \\
120 \\
150\end{array}$ & $\begin{array}{l}21 \\
11 \\
11\end{array}$ & 200 \\
\hline $\begin{array}{l}181212- \\
\text { lot.4-1 }^{\mathrm{e}, \mathrm{f}}\end{array}$ & 1 & $\begin{array}{l}2 \mathrm{~L} \\
1.2 \mathrm{U} \\
2 \mathrm{~B}\end{array}$ & $\begin{array}{r}1200 \\
1200 \\
230\end{array}$ & $\begin{array}{r}210 \\
80 \\
140\end{array}$ & $\begin{array}{l}11 \\
23 \\
14\end{array}$ & 200 \\
\hline $\begin{array}{l}\text { 181001- } \\
\text { lot.3-2 }\end{array}$ & 0.44 & $\begin{array}{l}2 \mathrm{~L} \\
1.2 \mathrm{U}\end{array}$ & $\begin{array}{l}1200 \\
1200\end{array}$ & $\begin{array}{l}170 \\
250\end{array}$ & $\begin{array}{l}22 \\
30\end{array}$ & 350 \\
\hline $\begin{array}{l}\text { 181212- } \\
\text { lot.4-2 }^{\mathrm{f}}\end{array}$ & 0.44 & $\begin{array}{l}2 \mathrm{~L} \\
2 \mathrm{~L} \\
1.2 \mathrm{U} \\
2 \mathrm{~B}\end{array}$ & $\begin{array}{r}1200 \\
1200 \\
1200 \\
230\end{array}$ & $\begin{array}{l}110 \\
160 \\
160 \\
180\end{array}$ & $\begin{array}{l}23 \\
17 \\
20 \\
21\end{array}$ & 350 \\
\hline $\begin{array}{l}181001- \\
\text { lot.3-3 }\end{array}$ & 0.26 & $\begin{array}{l}2 \mathrm{~L}^{\mathrm{g}} \\
2 \mathrm{~B}\end{array}$ & $\begin{array}{r}1200 \\
230\end{array}$ & $\begin{array}{l}730 \\
780 \\
\end{array}$ & $\begin{array}{l}5 \\
4\end{array}$ & 490 \\
\hline $\begin{array}{l}\text { 181212- } \\
\text { lot.4-3 }^{\mathrm{f}}\end{array}$ & 0.26 & $\begin{array}{l}2 \mathrm{~L} \\
1.2 \mathrm{U} \\
2 \mathrm{~B}\end{array}$ & $\begin{array}{r}1200 \\
1200 \\
230\end{array}$ & $\begin{array}{l}700 \\
500 \\
700\end{array}$ & $\begin{array}{l}5 \\
7 \\
4\end{array}$ & 490 \\
\hline $\begin{array}{l}\text { 181001- } \\
\text { lot.3-4 }\end{array}$ & 0.09 & $\begin{array}{l}2 \mathrm{~L} \\
1.2 \mathrm{U} \\
2 \mathrm{~B}\end{array}$ & $\begin{array}{r}1200 \\
1200 \\
230\end{array}$ & $\begin{array}{r}1000 \\
970 \\
1000\end{array}$ & $\begin{array}{l}5 \\
4 \\
4\end{array}$ & 1000 \\
\hline $\begin{array}{l}\text { 181212- } \\
\text { lot.4-4 }\end{array}$ & 0.09 & $\begin{array}{l}2 \mathrm{~L} \\
2 \mathrm{~L}\end{array}$ & $\begin{array}{l}1200 \\
1200\end{array}$ & $\begin{array}{l}1200 \\
1200\end{array}$ & $\begin{array}{l}4 \\
5\end{array}$ & 1000 \\
\hline $\begin{array}{l}\text { 181001- } \\
\text { lot.3-5 }\end{array}$ & 0.03 & $\begin{array}{l}2 \mathrm{~L} \\
1.2 \mathrm{U} \\
2 \mathrm{~B}\end{array}$ & $\begin{array}{r}1200 \\
1200 \\
230\end{array}$ & $\begin{array}{l}2700 \\
2300 \\
2500\end{array}$ & $\begin{array}{l}3 \\
4 \\
6\end{array}$ & 2000 \\
\hline $\begin{array}{l}\text { 181212- } \\
\text { lot.4-5 }^{\mathrm{f}}\end{array}$ & 0.03 & $\begin{array}{l}2 \mathrm{~L} \\
2 \mathrm{~L} \\
1.2 \mathrm{U} \\
2 \mathrm{~B}\end{array}$ & $\begin{array}{r}1200 \\
1200 \\
1200 \\
230\end{array}$ & $\begin{array}{l}3000 \\
3000 \\
1600 \\
1000\end{array}$ & $\begin{array}{l}3 \\
3 \\
5 \\
4\end{array}$ & 2000 \\
\hline
\end{tabular}

Caption:

a: Ti samples: $\sim 1.0 \mathrm{~g}, 2 \mathrm{~L}$ : wire with $2 \mathrm{~mm}$ diameter wire, $1.2 \mathrm{U}: 1.2 \mathrm{~mm}$ diameter wire, 2B: cube with $2 \mathrm{~mm}$ side length

b: Activity of Y $(s)$.

c: Theoretical deoxidation limit of Ti.

$\mathrm{d}$ : Analytical conditions:

Standard sample: steel pin $\sim 1.0 \mathrm{~g}, 365 \pm 7 \mathrm{ppm}$ O, part number: 501-646

Graphite crucible: $\sim 1.0 \mathrm{~g}, 0.1 \pm 0.1 \mu \mathrm{g} \mathrm{O}$, part number: $782-720$

Ni flux: $\sim 1.0 \mathrm{~g}, 4.4 \pm 1.9 \mu \mathrm{g} \mathrm{O}$, part number: $502-344$

Estimated maximum analytical error: $\varepsilon_{0, \max }=30 \%$,

e: These values are reprinted from ref. 53 .

f: Analytical conditions:

Standard sample: steel pin $\sim 1.0 \mathrm{~g}, 365 \pm 7 \mathrm{ppm}$ O, part number: 501-646

Graphite crucible: $\sim 1.0 \mathrm{~g}, 0.0 \pm 0.1 \mu \mathrm{g} \mathrm{O}$, part number: $782-720$

Ni flux: $\sim 1.0 \mathrm{~g}, 3.4 \pm 1.5 \mu \mathrm{g} \mathrm{O}$, part number: $502-344$

Estimated maximum analytical error: $\varepsilon_{\mathrm{O}, \max }=23 \%$ g: Two piece.

$\mathrm{HNO}_{3}-\mathrm{H}_{2} \mathrm{O}$ for approximately $30 \mathrm{~s}$. Scanning electron microscopy (SEM) and energy-dispersive X-ray spectroscopy (EDS) were used to analyze the microstructure and the composition of the Ti pellet (JSM6510LV, JEOL Co., Ltd.).

\section{Results and Discussions}

\subsection{Inert gas fusion analysis of $\mathrm{Ti}$ samples in the $\mathrm{Y} /$ $\mathrm{Y}_{2} \mathrm{O}_{3}$ equilibrium}

Table 6 shows the $\mathrm{O}$ concentration in the Ti samples after the experiment in the $\mathrm{Y} / \mathrm{Y}_{2} \mathrm{O}_{3}$ equilibrium. Figure 7 shows the relationship between the experimentally obtained $\mathrm{O}$ concentrations in $\mathrm{Ti}$ and $a_{\mathrm{Y}}$ in the $\mathrm{Y}-\mathrm{Ag}$ alloy. As shown in Fig. 7, the results are in good agreement with calculated values using thermodynamics. These results indicate that the $\mathrm{O}$ concentration in $\mathrm{Ti}$ can be controlled reliably in the range of 200-2000 ppm O using the method designed in this study.

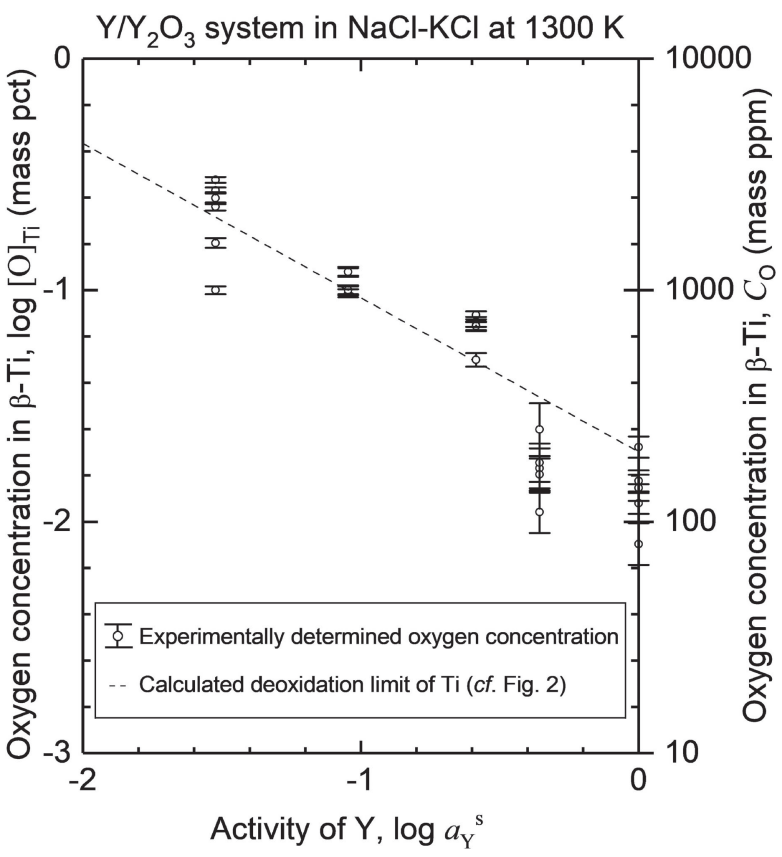

Fig. 7 The relationship between experimentally obtained oxygen concentration in the Ti samples and $a_{\mathrm{Y}}$ in $\mathrm{Y} / \mathrm{Y}_{2} \mathrm{O}_{3}$ equilibrium.

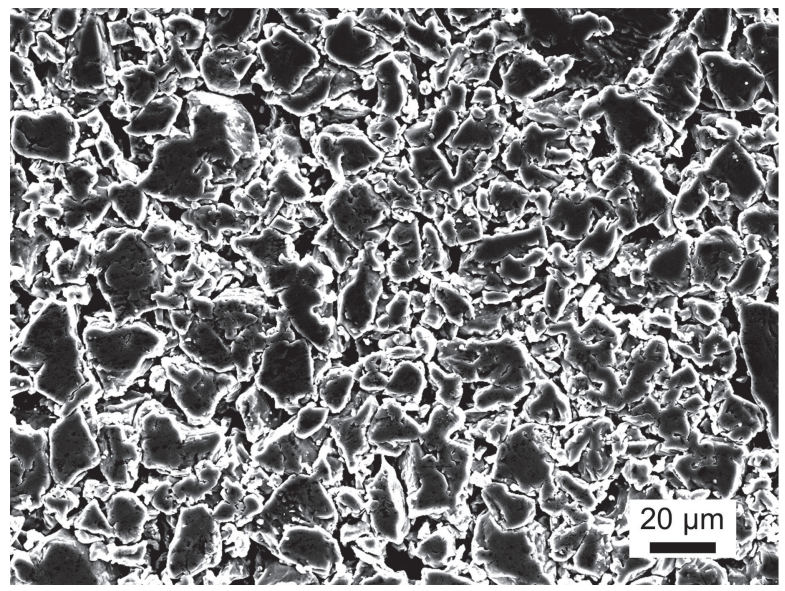

Fig. 8 SEM image of the surface of Ti pellets in $\mathrm{NaCl}-\mathrm{KCl}$ at $1300 \mathrm{~K}$ before the experiment.

4.2 SEM observation and EDS mapping of Ti pellets in the $\mathrm{Y} / \mathrm{Y}_{2} \mathrm{O}_{3}$ equilibrium and $\mathrm{Y} / \mathrm{YOCl} / \mathrm{YCl}_{3}$ equilibrium

Figure 8 shows the SEM image of the surface of the Ti pellet before the experiment.

Figure 9 shows the EDS mapping of a cross-section of a Ti pellet in the experiment in the $\mathrm{Y} / \mathrm{Y}_{2} \mathrm{O}_{3}$ equilibrium, in which pure $\mathrm{Y}$ metal was employed in molten $\mathrm{NaCl}-\mathrm{KCl}$ (Exp. \# 181001-lot.3-1). Comparison of the SEM images in Figs. 8 and 9(a) indicates that sintering of $\mathrm{Ti}$ powder occurred. However, as shown in Fig. 9(a), the driving force for the sintering reaction of Ti powder was not high enough to obtain a completely dense sintered body. Furthermore, Y was observed in the Ti pellet (Fig. 9(e)), which means Y contamination was occurred in the Ti pellet. In contrast, the positions of the $\mathrm{O}$ and chlorine $(\mathrm{Cl})$ signals in the Ti pellet were unclear (Figs. 9(b), (c)). Y contamination was likely 
(a)

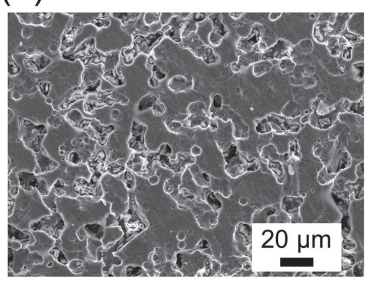

(c)

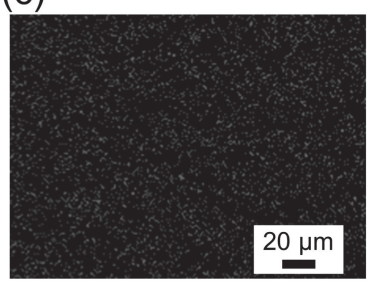

(e)

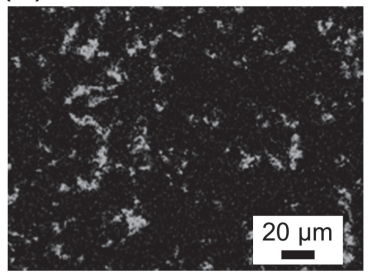

Fig. 9 EDS-mapping of the cross-section of a Ti pellet in the $\mathrm{Y} / \mathrm{Y}_{2} \mathrm{O}_{3}$ equilibrium, after the sintering experiment (exp.181001-lot.3-1): (a) SEM image, (b) $\mathrm{O}$, (c) $\mathrm{Cl}$, (d) Ti, and (e) Y. (a)

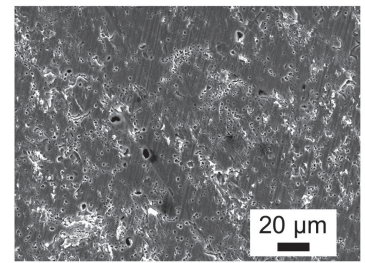

(c)

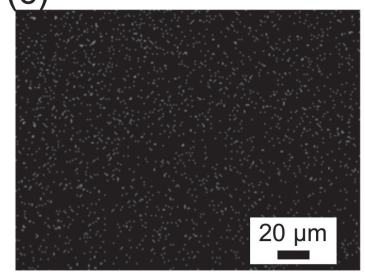

(e)

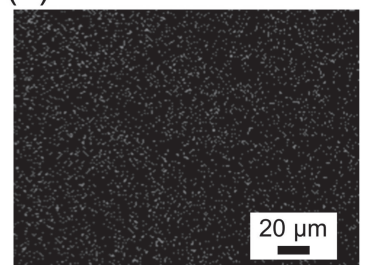

(b)

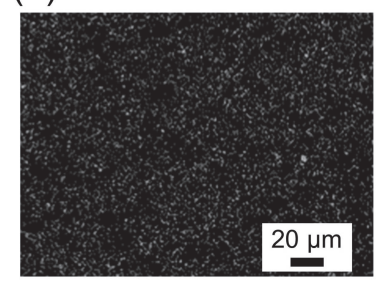

(d)

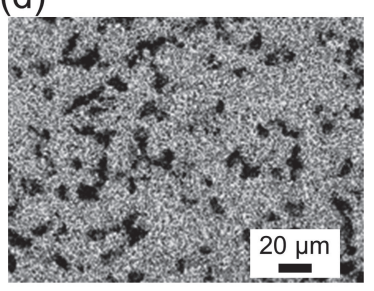

\#190315-lot.6-1). Figure 10 confirms that sintering occurred in this system and the sintered Ti pellet was still porous. The positions of $\mathrm{Y}, \mathrm{O}$, and $\mathrm{Cl}$ were not identified during the EDS mapping.

In this study, we focused mainly on thermodynamics in order to probe the deoxidation limits during the sintering process. Thus, the temperature $(1300 \mathrm{~K})$ was set to be lower than the general sintering temperature of PM-Ti (1500$1700 \mathrm{~K})$. However, the sintering/deoxidation temperature is changeable. Higher temperatures would increase the driving force of the sintering reaction under the ultra-low $p_{\mathrm{O}_{2}}$ environment.

As mentioned, this study demonstrated that new deoxidation methods using the $\mathrm{Y} / \mathrm{Y}_{2} \mathrm{O}_{3}$ and $\mathrm{Y} / \mathrm{YOCl} / \mathrm{YCl}_{3}$ equilibria are effective to control the $\mathrm{O}$ concentrations in $\mathrm{Ti}$, and that the sintering reaction of Ti powder proceeds in molten salt at $1300 \mathrm{~K}$. However, some problems, such as contamination and porousness in the sintered $\mathrm{Ti}$, remain to be solved before this deoxidation method can be applied to $\mathrm{PM}-\mathrm{Ti}$ in practice. The establishment of this new process will enable the efficient fabrication of Ti products with desired low-O-concentration from low-cost high-O-concentration Ti powder.

\section{Conclusion}

In this study, we developed a new sintering process that could remove $\mathrm{O}$ from Ti using Y metal in molten salt. This study showed that the $\mathrm{O}$ concentration in Ti could be reliably controlled by varying the activity of $\mathrm{Y}$ in the $\mathrm{Y} / \mathrm{Y}_{2} \mathrm{O}_{3}$ equilibrium in $\mathrm{NaCl}-\mathrm{KCl}(l)$ and that the sintering of $\mathrm{Ti}$ powder co-occurred. Additionally, when the $\mathrm{Y} / \mathrm{YOCl} / \mathrm{YCl}_{3}$ equilibrium was employed to reduce the $\mathrm{O}$ concentration in Ti to $30-60 \mathrm{ppm} \mathrm{O}$ in $\mathrm{YCl}_{3}(l)$, the sintering of Ti powder also proceeded. This study demonstrated the possibility of the development of a new sintering process, in which the $\mathrm{O}$ concentration of Ti can be controlled to 30-2000 ppm O. (d)

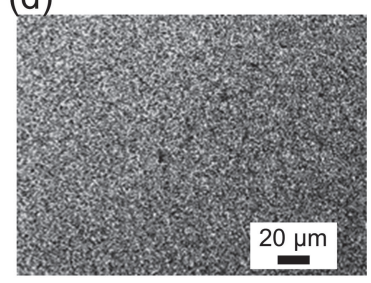

Fig. 10 EDS-mapping of the cross-section of a Ti pellet in the $\mathrm{Y} / \mathrm{YOCl} /$ $\mathrm{YCl}_{3}$ equilibrium, after the sintering experiment (exp.190315-lot.6-1): (a) SEM image, (b) O, (c) Cl, (d) Ti, and (e) Y.

caused from contact between the Ti powder and $\mathrm{Y}$ ions in the molten salt.

Figure 10 shows the EDS mapping of a cross-section of a Ti pellet in the $\mathrm{Y} / \mathrm{YOCl} / \mathrm{YCl}_{3}$ equilibrium in $\mathrm{YCl}_{3}$ (Exp.

\section{Acknowledgments}

We are grateful to Dr. Lingxin Kong and Mr. Takara Tanaka at The University of Tokyo for their helpful suggestions and help with the experiments. This work was financially supported by the Japan Society for the Promotion of Science (JSPS) through a Grant-in-Aid for Scientific Research (S) (KAKENHI Grant No. 26220910, and 19H05623).

\section{REFERENCES}

1) M.F. Ashby: Materials Selection in Mechanical Design, third ed., (Butterworth-Heinemann, Burlington, U.S., 2005).

2) M. Niinomi: Mater. Sci. Eng. A 243 (1998) 231-236.

3) The Japan Titanium Society: Titan (Gemba De Ikasu Kinzoku Zairyo Series) in Japanese, (Maruzen, Tokyo, Japan, 2011).

4) B.H. Kasemo: J. Prosthet. Dent. 49 (1983) 832-837.

5) K.K. Turekian and K.H. Wedepohl: Geol. Soc. Am. Bull. 72 (1961) 175-192.

6) U.S. Department of the Inventor and U.S. Geological Survey, Mineral Commodity Summaries 2019. https://www.usgs.gov/centers/nmic/ mineral-commodity-summaries/, 2019 (accessed on 6 January 2020).

7) O. Takeda and T.H. Okabe: JOM 71 (2019) 1981-1990. 
8) M. Yamaguchi, M. Yamaguchi and R.O. Suzuki: Titanium Japan 54 (2006) 78-82 (in Japanese).

9) D.J. Fray: Int. Mater. Rev. 53 (2008) 317-325.

10) Z.Z. Fang, J.D. Paramore, P. Sun, K.S.R. Chandran, Y. Zhang, Y. Xia, F. Cao, M. Koopman and M. Free: Int. Mater. Rev. 63 (2018) $407-$ 459.

11) P.C. Rath: SGAT Bulletin 17 (2016) 10-23.

12) Y. Ito: doctoral thesis in Kyushu University, (2015, in Japanese).

13) R.I. Jaffee, H.R. Ogden and D.J. Maykuth: JOM 2 (1950) 1261-1266.

14) H.R. Odgen and R.I. Jaffee: Titanium Metallurgical Laboratory Report, (Battelle Memorial Institute, Ohio, U.S., 1955) Vol. 20.

15) T.H. Okabe, T. Oishi and K. Ono: J. Alloy. Compd. 184 (1992) 43-56.

16) M. Yan, W. Xu, M.S. Dargusch, H.P. Tang, M. Brandt and M. Qian: Powder Metall. 57 (2014) 251-257.

17) L. Lefebvre, E. Baril and L. Camaret: J. Mater. Res. 28 (2013) 2453 2460 .

18) L. Grainger: Additive World Conference II, March 27th 2014, https:// additiveworld.com/Conferences/Additive-world-conference-2014 (accessed on 6 January 2020).

19) Powder Metallurgy Review, Metalysis' titanium powder used to $3 \mathrm{D}$ print automotive parts, https:/www.pm-review.com/metalysistitanium-powder-used-to-3d-print-automotive-parts/ (accessed on 6 January 2020)

20) S. Abkowitz, J.M. Siergiej and R.D. Regan: Parts and Composites, Modern Developments in Powder Metallurgy, (Metal Powder Industries Federation, Princeton, NJ, 1971) Vol. 4, pp. 501-511.

21) K. Majima, T. Isono and K. Shoji: J. Jpn. Soc. Powder Powder Metall. 33 (1986) 28-33 (in Japanese).

22) P.K. Tripathy, M. Gauthier and D.J. Fray: Metall. Mater. Trans. B 38 (2007) 893-900.

23) L. Strezov, I. Ratchev, S. Osborn and K. Mukunthan: US Paten No. 7156974 B2, (2007)

24) J.-C. Choi, S.-H. Chang, Y.-H. Cha and I.-H. Oh: Korean J. Mater. Res. 19 (2009) 397-402.

25) A.T. Sidambe, I.A. Figueroa, H.G.C. Hamilton and I. Todda: J. Mater Process. Technol. 212 (2012) 1591-1597.

26) S.D. Luo, C.L. Guan, Y.F. Yang, G.B. Schaffer and M. Qian: Metall Mater. Trans. A 44 (2013) 1842-1851.

27) E. Carreño-Morelli, J.-E. Bidaux, M. Rodríguez-Arbaizar, H. Girard and H. Hamdan: Powder Metall. 57 (2014) 89-92.

28) J.M. Oh, I.H. Choi, C.Y. Suh, H. Kwon, J.W. Lim and K.M. Roh: Met. Mater. Int. 22 (2016) 488-492.

29) Z.Z. Fang, P. Sun, Y. Xia and Y. Zhang: US Patent No. 2017/0113273 A1, (2017).

30) D. Hu and G.Z. Chen: ECS Trans. 50 (2013) 29-37.

31) D. Hu, A. Dolganov, M. Ma, B. Bhattacharya, M.T. Bishop and G.Z. Chen: JOM 70 (2018) 129-137.

32) T. Maetani, T. Maetani, J. Ota and H. Suzuki: Japan Patent, JPH0790318A, (1993)

33) T.-W. Na, W.R. Kim, S.-M. Yang, O. Kwon, J.M. Park, G.-H. Kim,
K.-H. Jung, C.-W. Lee, H.-K. Park and H.G. Kim, Mater. Charact. 143 (2018) 110-117.

34) H.-K. Park, T.-W. Na, S.-M. Yang, G.-H. Kim, B.-S. Lee and H.G. Kim: Mater. Lett. 236 (2019) 106-108.

35) T.H. Okabe, R.O. Suzuki, T. Oishi and K. Ono: Mater. Trans. JIM 32 (1991) 485-488.

36) J.-M. Oh, B.-K. Lee, C.-Y. Suh, S.-W. Cho and J.-W. Lim: Powder Metall. 55 (2012) 402-404.

37) J.W. Lim, J.M. Oh, B.K. Lee, C.Y. Suh and S.W. Cho: US Patent No. 8,449,813, (2013).

38) J.W. Lim, J.M. Oh, B.K. Lee, C.Y. Suh and S.W. Cho: US Patent No. 8,449,646, (2013)

39) J.-M. Oh, H. Kwon, W. Kim and J.-W. Lim: Thin Solid Films 551 (2014) 98-101.

40) J.-M. Oh, C.-Y. Suh, H. Kwon, J.-W. Lim and K.-M. Roh: J. Korean Inst. Resour. Recycling 24 (2015) 21-27 (in Korean).

41) S.-J. Kim, J.-M. Oh and J.-W. Lim: Met. Mater. Int. 22 (2016) 658662.

42) C.-I. Hong, J.-M. Oh, J. Park, J.-M. Yoon and J.-W. Lim: Adv. Powder Technol. 29 (2018) 1640-1643.

43) J.-M. Oh, C.-I. Hong and J.-W. Lim: Adv. Powder Metall. 30 (2019) $1-5$.

44) G.Z. Chen, D.J. Fray and T.W. Farthing: Nature 407 (2000) 361-364.

45) Roskill Information Services, Rare Earths: Global Industry, Markets and Outlook to 2026, 16th ed., (London, U.K., 2016).

46) M. Yang, H.P. Tang and M. Qian: Titanium Powder Metallurgy, (Elsevier, Waltham, U.S., 2015) pp. 253-276.

47) Y.F. Yang, S.F. Li, M. Qian, Q.S. Zhu, C.Q. Hu and Y. Shi: J. Alloy. Compd. 764 (2018) 467-475.

48) B. Poorganji, A. Kazahari, T. Narushima, C. Ouchi and T. Furuhara: J. Phys. Conf. Ser. 240 (2010) 012170.

49) T.H. Okabe, T. Deura, T. Oishi, K. Ono and D.R. Sadoway: J. Alloy. Compd. 237 (1996) 150-154.

50) T.H. Okabe, T. Deura, T. Oishi, K. Ono and D.R. Sadoway: Metall. Trans. B 27 (1996) 841-847.

51) T.H. Okabe, K. Hirota, E. Kasai, F. Saito, Y. Waseda and K.T. Jacob: J. Alloy. Compd. 279 (1998) 184-191.

52) T.H. Okabe, K. Hirota, Y. Waseda and K.T. Jacob: J. MMIJ 114 (1998) 813-818.

53) A. Iizuka, T. Ouchi and T.H. Okabe: Metall. Mater. Trans. B, in press doi:10.1007/s11663-019-01742-6 (accessed on 6 January 2020).

54) I. Barin: Thermochemical Data of Pure Substances, third ed., (VCH Verlagsgesellschaft mbH, Weinheim, Germany, 1995).

55) Y.B. Patrikeev, G.I. Novikov and V.V. Badovskii: Russ. J. Phys. Chem. 47 (1973) 284

56) C.E. Lundin and D.T. Klodt: Trans. Met. Soc. AIME 224 (1962) 367372 .

57) O. Madelung: Landolt-Börnstein - Group IV Physical Chemistry book series, (Berlin, Germany, 1991).

58) C.J. Rosa: Metall. Trans. 1 (1970) 2517-2522. 